\title{
Ornamental potential of the coastal plant Lapiedra martinezii Lag. (Amaryllidaceae): the role of its revalorization in xero-gardening and ex-situ conservation
}

\author{
Potencial ornamental de Lapiedra martinezii Lag. (Amaryllidaceae): implicaciones de su \\ revalorización en xerojardinería y en su conservación ex-situ
}

Fecha de recepción y aceptación: 22 de febrero de 2021 y 28 de junio de 2021

DOI: $10.46583 /$ nereis 2021.13 .581

\author{
Jorge Juan-Vicedo ${ }^{1 *}$, Emilio Laguna², Segundo Ríos ${ }^{3}$ and José Luis Casas ${ }^{3}$ \\ ${ }^{1}$ Instituto de Investigación en Medio Ambiente y Ciencia Marina IMEDMAR. \\ ${ }^{*}$ Correspondencia: Universidad Católica de Valencia San Vicente Mártir. Instituto de Investigación en Medio Ambiente y Ciencia \\ Marina (IMEDMAR).Calle Guillem de Castro, 94. 46001 Valencia. Spain. E-mail: jorge.juan@ucv.es \\ ${ }^{2}$ Wildlife Service. Department of Infrastructure, Territory and Environment of the Valencian Government-Center of Forestry Re- \\ search and Experimentation CIEF. \\ ${ }^{3}$ Research Institute of Biodiversity. University of Alacant.
}

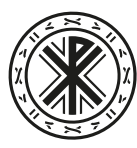

Universidad Católica de Valencia San Vicente Mártir

\begin{abstract}
Lapiedra martinezii Lag. (Amaryllidaceae) is an autumn-flowering geophyte that grows in coastal and sublittoral environments. The interest in this species has emerged during recent decades due to its bioactive alkaloid content and its conservational status. The aim of this work was to review the available information on L. martinezii and to assess whether it could be introduced as an ornamental plant in xero-gardening. Therefore, its aesthetic appeal was reviewed and compared to other cultivated and wild plants. Also, information on its ecological and propagation requirements were checked to discern whether it could be adapted under different production systems and culture conditions. In addition, other aspects were also analyzed to identify strengths and limitations of this species for its further revalorization as an ornamental plant. The results obtained suggest that $L$. martinezii could be a good choice as a foliage plant for growing in gardens as an alpine bulb or pot plant. Moreover, it might be quite well adapted under different production and culture conditions to dry and semi-arid regions. The horticultural traits related to its germination and in vitro multiplication are interesting strengths to bear in mind for its industrial propagation and early domestication. Finally, its introduction in xero-gardening could also help in its ex-situ conservation. However, a more in-depth study would be needed to definitively introduce it into the ornamental plant market.
\end{abstract}

KEYWORDS: Lapiedra martinezii, xero-gardening, coastal plants, horticulture, ex situ conservation, bulbous plants. 


\section{RESUMEN}

Lapiedra martinezii Lag. (Amaryllidaceae) es un geófito bulboso de floración otoñal que vive en ambientes costeros y sublitorales. El interés en esta especie ha crecido durante las últimas décadas debido a su contenido en alcaloides bioactivos y a su estado de conservación. El objetivo de este trabajo fue revisar la información disponible sobre L. martinezii y evaluar si podría ser introducido como planta ornamental en xerojardinería. Por tanto, los caracteres estéticos fueron analizados y comparados con otras plantas cultivadas y silvestres. También, se estudia la información disponible acerca de sus requerimientos ecológicos y de propagación para detector si podría ser adaptada en distintos sistemas de producción y condiciones de cultivo. Además, otros aspectos fueron analizados para identificar tanto las fortalezas como las limitaciones de esta especie en su posterior revalorización como planta ornamental. Los resultados obtenidos sugieren que L. martinezii podría ser una buena opción como planta ornamental de follaje para su cultivo en jardines como bulbo de rocalla o planta de maceta. Además, podría adaptarse bastante bien a distintos sistemas de producción y condiciones de cultivo en regiones secas y semiáridas. Las características hortícolas relacionadas con la germinación y multiplicación in vitro son fortalezas interesantes para tener en cuenta en su puesta en cultivo a escala industrial y su domesticación preliminar. Finalmente, la introducción de esta especie en xerojardinería podría también ayudar a su conservación ex situ. Sin embargo, sería deseable una investigación más profunda para su inclusion en el mercado convencional de planta ornamental.

PALABRAS CLAVE: Lapiedra martinezii, xerojardinería, plantas costeras, horticultura, conservación ex situ, plantas bulbosas.

\section{INTRODUCTION}

Over recent decades, the purchase of ornamental products in the western world has increased along with the improvement of living standards. In particular, in the 1970s the remarkable increase in the value of domestic production was a clear sign of a transition toward specialized floriculture [1, 2]. In Europe, the Netherlands has traditionally been the largest producer, importer from third countries, and the largest exporter both outside and inside the European Union [1-5]. Specifically, flower bulb exports totalled $\$ 756$ million in 2005 [6] and increased up to $\$ 1,045.8$ million in 2015 [7]: \$133.1 was exported to Germany, $\$ 121.8$ to the USA and $\$ 81.6$ to China. In the Mediterranean countries, the ornamental plant industry (floriculture, pot plant and ornamental tree production) remains an important economical activity $[1,2,8]$. In the specific case of Spain, the economic returns from ornamentals rank among the highest and, from a productivity standpoint, ornamentals appear at the top of productivity for Spanish agriculture. Likewise, ornamentals have usually been net contributors to the Spanish balance of payments over the previous decade [8]. However, data on the flowering bulb industry is missing in this country, most probably due to the lack of specialisation in this subsector, which has been traditionally located in the Netherlands and Great Britain (mainly) but also in Germany, United States and Israel [3-6]. The use of exotic plant species as ornamentals has been a common practice all over the world. However, one of the main problems of using exotic plants has been the introduction of invasive species with the subsequent management and conservation problems in local landscapes [2,9]. Recent trends in landscaping and gardening under semiarid conditions include the use of halophytes and/or drought-adapted plants $[9,10]$. In line with this, native 
geophytes are promising ornamental species because they have low thermal requirements, a short growing cycle and they are highly resilient to adverse seasons. Also, they prefer light or medium-consistency soils such as limestone with a moderate quantity of water and organic matter. They need less fertilization than other species, having reserve organs that accumulate significant amounts of nutrients $[2,11]$. In general, native ornamentals with low water requirements (and paramount examples are the olive tree, dwarf palm and other palm trees) dominate the markets in xero-gardening in Mediterranean countries [8]. Therefore, native bulbs belonging to dry and semi-arid environments have economical potential as their production costs and gardening maintenance are lower as well as the risk of ecological imbalance and invasion is significantly reduced in comparison to other life forms. In Spain, several works on revalorization of native flora (Ericaceae, Lamiaceae, etc) have been published during recent years with a focus on their potential use in xero-gardening [6,11-14]. However, bulbous plants are normally missing in these strategies and none of them took into account any Amaryllidaceae. The Amaryllidaceae are economically important as ornamentals in the European horticultural industry: there are a plethora of plants belonging to this family available in the conventional gardening inventory, with Narcissus being one of the genera that has dominated the market because numerous species, commercial cultivars and forms are commonly available in the usual shops, garden centres or over the internet, both in bulb and seed formats $[3,6,15]$. In addition, some endemic, rare or even threatened species of Spanish Amaryllidaceae are sold over the internet, including taxa from the genera Narcissus and Pancratium, (http://www.rareplants.co.uk). In contrast, other endemic plants remain practically unknown by most of the public such as some wild bulbs from semi-arid areas. Lapiedra martinezii Lag. has aroused certain interest by botanists from non-Mediterranean countries in their harvesting campaigns $[4,16]$ and its presence has been recently noticed in few seed and bulb collections, selected gardening forums and other specialised platforms (e.g. https://www.rhs.org.uk/; http://telosrarebulbs.com). However, it has still not been taken into account in the general gardening plant inventory. L. martinezii is endemic in the South-west Mediterranean, mainly distributed in some coastal regions of Spain and North Morocco [16-20]. Also, this species has great economical potential due to its content in biologically active alkaloids [21-24]. Therefore, the aim of this work was to review and assess the potential use of $L$. martinezii as a gardening plant both for conventional horticulture and/or xero-gardening, as well as to discuss the implications of such use in the conservation of this species.

\section{METHODOLOGY}

Literature data were retrieved using the ISI Web of Knowledge and Google Scholar databases, as well as checking local flora [17-20, 25, 26]; doctoral thesis [84] books, virtual libraries, etc. To analyse the ornamental potential of $L$. martinezii we reviewed the morphological, phenological, ecological and physiological features of this species found in the above-mentioned sources, as well as compared to other popular plants. All entries until September 2019 were considered and primary data was first screened. Review literature not containing additional data to articles previously cited have deliberately not been cited in this manuscript. For the correct spelling of the Latin names of the plants, as well as to cite the authors properly, we have followed The Plant List (http://www.theplantlist.org/). All this information was critically analysed and discussed to finally assess the potential use of L. martinezii as a gardening plant both for conventional horticulture and/or xero-gardening. 


\section{RESULTS}

\section{Botanical description and aesthetic traits}

The genus Lapiedra Lag. has only one described species in the world: L. martinezii. Two other species initially included in this genus were transferred to other genera: L. chilensis F. Phil. ex Phil. (currently considered as a synonym of Traubia modesta (Phil.) Ravena) and L. gracilis Baker, a synonym of Narcissus cavanillesii Barra \& G. López. Another name, L. placiana Herb. is recognized nowadays as a synonym of $L$. martinezii. It is a small geophyte whose height ranges from 15 up to 75 $\mathrm{cm}$ [22], and may be even smaller 14-34 cm [17]. The flowers are white, actinomorphic, with 6 persistent petals and grouped in apical pseudo-umbrella inflorescences (figure 1) bearing (4)6 - 13(14) flowers that are slightly fragrant, $2-3 \mathrm{~cm}$ long with scariose margin into two bracts, exceptionally three [22]. L. martinezii is a late-summer/early-autumn flowering species. Flowers and leaves do not normally show contemporaneous development and the latter appear after the flowering period and last about eight months until early summer [17, 22], thus showing a semi-evergreen behaviour (figure 1). The bulb measures 2.6-6.5 x 2.4-6.7 cm [17]. Each bulb produces (1)2-4(5) narrow linear leaves of dark-green colour with glossy aspect and a typical central whitish band (figure 1). In nature, vegetative propagation frequently takes place by subequal division into 2-3 or more, so that the new bulbs appear in tightly grouped colonies [22]. According to [17], 2-3 leaves are present per bulb (exceptionally 5), with measurements of 3-17(47) $\times(0.2) 0.6-1.3(2.1) \mathrm{cm}$, linear-shaped, with smooth margin, briefly attenuated and \pm obtuse at apex. Personal observations made in culture conditions, under shady exposure site and regular watering, shows that leaves become much longer (up to $50-53 \mathrm{~cm}$ ) and wider (up to $2.4 \mathrm{~cm}$ ).

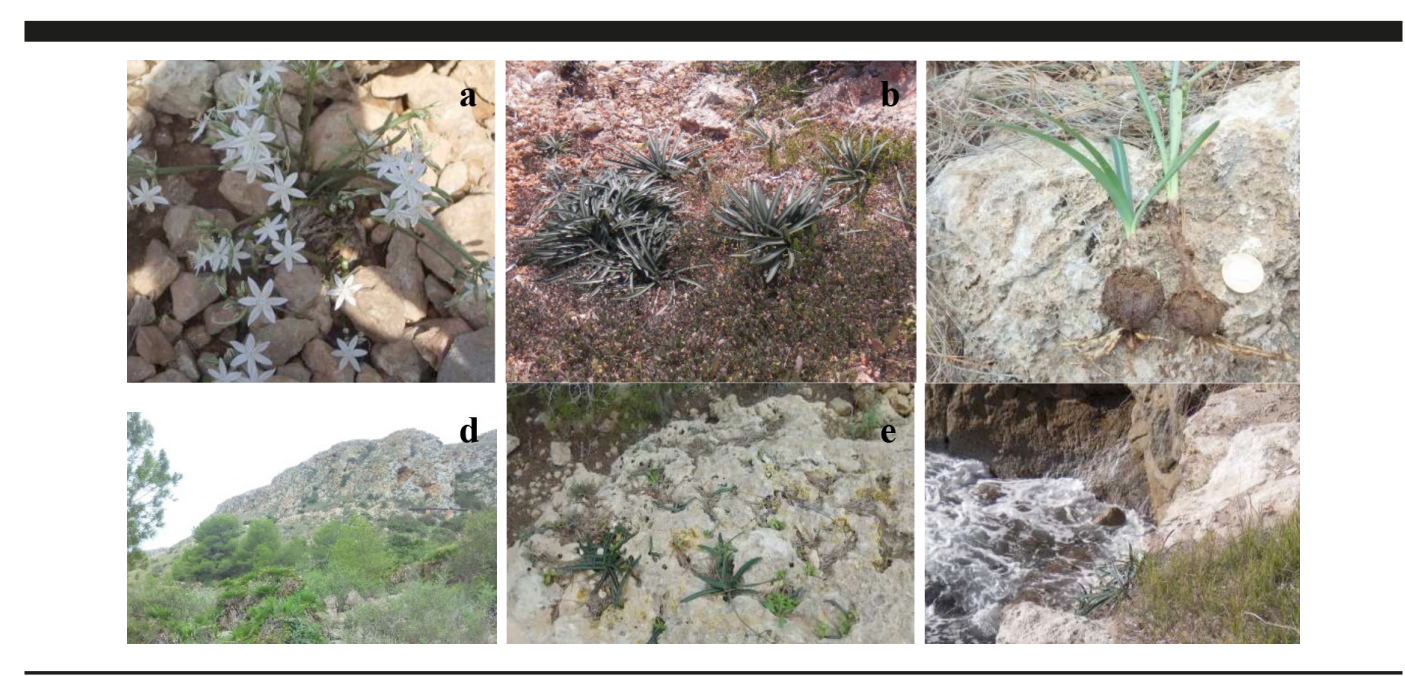

Fig. 1. Lapiedra martinezii Lag. plant habit (whole plant and detail of different parts) and the natural habitats where is usually found.: a) Flowering colony; b) Plant colonies during the vegetative period; c) Roots, bulbs and leaves in adult post-flowering individuals; d) Thermophilous and coastal plant communities with Chamaerops humilis L., Rhamnus lycioides L., Stipa tenacissima L. and Asparagus albus L. in the proximities of Santa Pola's Cape (Santa Pola, Spain); e) Plant individuals in rock crevices in Santa Pola; f) Population on coastal cliffs of Penyal d'Ifach (Calp, Spain). Source: own elaboration. 


\section{Ecology and distribution}

L. martinezii grows in coastal or sublittoral thermophilous and semiarid plant communities dominated or co-dominated by the dwarf palm Chamaerops humilis L., Osyris lanceolata Hochst. \& Steud. and Maytenus senegalensis (Lam.) Exell, in several types of Mediterranean macchias, in woodlands with Pistacia lentiscus L. and Quercus coccifera L. Also, it is commonly found in vertical rocky slopes, crevices and coastal cliffs (figure 1) ranging from the sea level up to 860 m.a.s.1. [17, 18, 22].

Although L. martinezii is more frequent in limestone [22] areas, it can be found in several soil types, from volcanic and metamorphic (schists, gneiss) to igneous rocks (quartzite, sandstone). $L$. martinezii is a Baetic-Moroccan endemism distributed in the Southwestern Mediterranean (figure 2), but most of its populations are in the Iberian Peninsula. In Spain, it grows from Malaga to Castellón (with dubious presence in Córdoba Province) and there is a single citation in North Africa in Morocco [17-19, 22, 28] (http://www.floravascular.com).

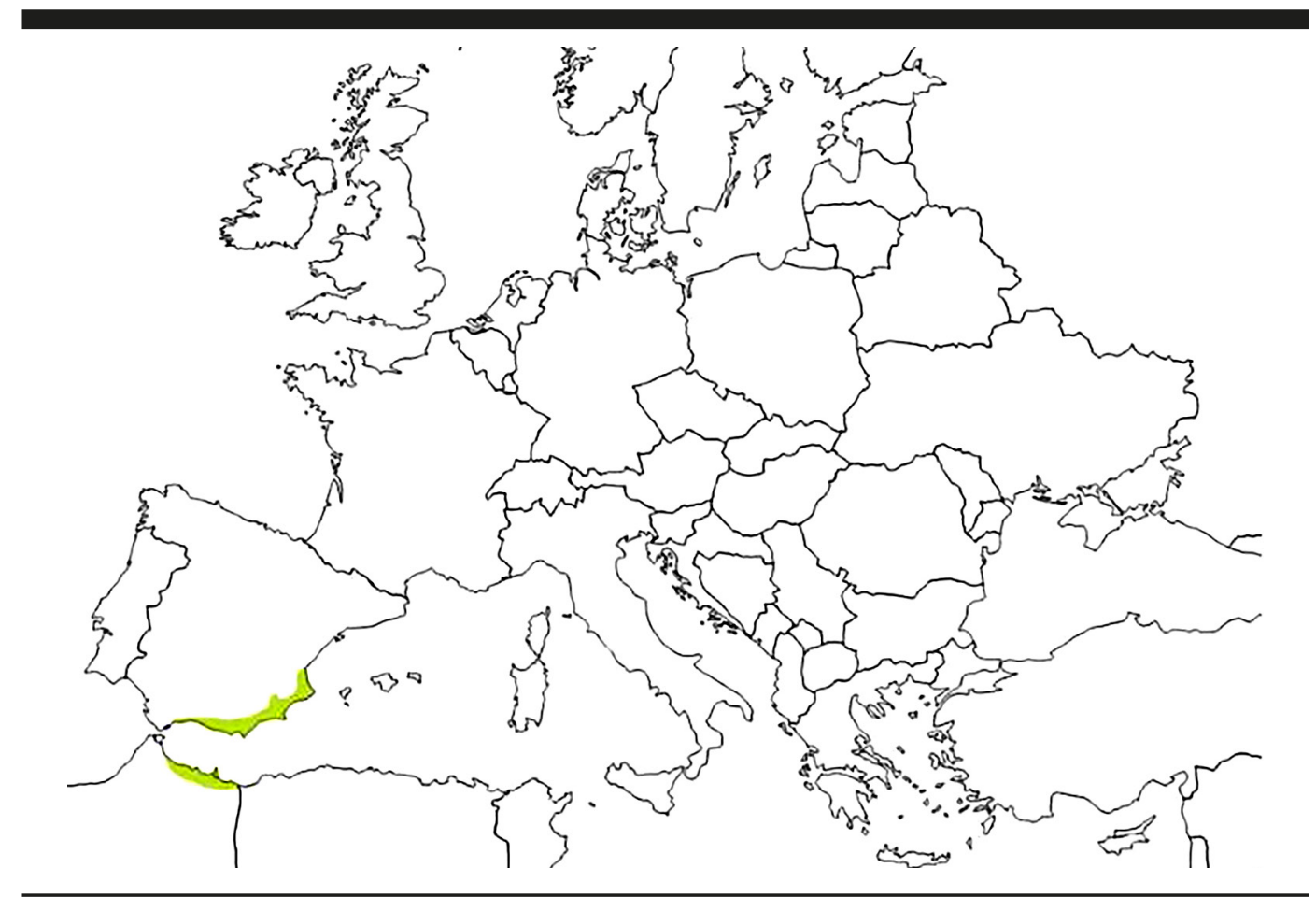

Fig. 2. Potential distribution of Lapiedra martinezii Lag. (green coloured areas) in the Mediterranean Basin. Redrawn from [18]. Source: own elaboration

\section{Horticultural traits}

L. martinezii can be propagated in the laboratory both sexually (by seeds) and asexually (bulbs). Experiments carried out on seed physiology showed that this species displayed a short morphological dormancy with further temperature-dependent seed germination. However, after one month of culture, final germination percentages were higher than $60 \%$ at $17{ }^{\circ} \mathrm{C}, 30 / 20{ }^{\circ} \mathrm{C}$ and $25 / 16{ }^{\circ} \mathrm{C}$, with 
optimum $(100 \%)$ at $20{ }^{\circ} \mathrm{C}$ regardless of the photoperiod applied. Below $17{ }^{\circ} \mathrm{C}$ germination was dramatically reduced [27]. As a result of the quick seedling establishment, bulbils rapidly appear from young plantlets thus constituting a suitable material for in vitro initiation, swelling and ex vitro acclimatization [84]. In vitro propagation from adult bulbs was also achieved and a yield of approximately 6 bulbils per explant were obtained using solid cultures supplemented with plant growth regulators after 8 weeks of cultivation [63]. In addition, increasing the sucrose concentration up to $90 \mathrm{~g} / \mathrm{L}$ in the culture medium almost doubled the biomass of bulbils produced in vitro [63]. However, the introduction under permanent and temporary immersion systems did not improve the results obtained on solid media in any case [84]. Callus induction was satisfactory using several plant growth regulators. However, none of the callus produced was able to be regenerated into new plants [63].

\section{DISCUSSION}

In Spain, ornamentals appear at the top of productivity for Spanish agriculture [8]. However, the strong influence of developing countries, the economic globalisation and the increase in production costs (energy and labour) can reduce the Spanish nursery gardening production to be like that of other developed countries [2]. The leading Spanish regions of the ornamental plant industry are Valencia and Catalonia with more than 1500 land hectares dedicated to this sector, followed by Andalusia and Murcia [8]. L. martinezii grows in thermophilous places in practically all these regions and therefore, there are horticulture enterprises located in the same area that could take the most advantage of this species. The use of native species for xero-gardening is also a promising option for the gardening and ornamental plant industry in Mediterranean countries [29-33]. Therefore, it seems quite reasonable to introduce endemic geophytes to this area in order to meet these objectives. However, selection and introduction of suitable gardening plants require comprehensive research on the plant's biology and is a very time-consuming task $[9,31]$. In addition, endemic plants often face conservation challenges derived from the human activities on their (more or less) restricted populations [34-39]. For this reason, we estimated the suitability of L. martinezii as a new commercial plant in the ornamental plant industry by addressing and discussing the following questions: What advantages does L. martinezii have in comparison to the aesthetic features of other conventional foliage plants? What advantages does $L$. martinezii present for its industrial production in xero-gardening? What advantages does $L$. martinezii present in comparison to other native bulbous plants? How the use of L. martinezii as an ornamental can affect the conservation status of its wild populations? What additional advantages does L. martinezii offer as a foliage plant?.

\section{What advantages does $L$. martinezii have in comparison to the aesthetic features of other con- ventional foliage plants?}

The semi-evergreen and bicolor leaves, along with the contrast of a glossy dark-green area with the central whitish band makes L. martinezii a very interesting ornamental grass as a foliage plant in borders, in a winter garden, or as an alpine bulb or pot plant. Among the most common foliage 
plants [40-43] (https://www.rhs.org.uk/) L. martinezii is broadly comparable in its aesthetic features to other conventional foliage ornamental cultivars such as the popular 'Spider plant' Chlorophytum comosum (Thunb.) Jacques (Asparagaceae) the 'Reed-canary grass' Phalaris arundinacea L. (Poaceae), the 'Lilyturf' Liriope muscari (Decne.) L.H.Bailey, the 'Liriopogons' in general (Liriope sp $\mathrm{pl}$ and Ophiopogon sp. pl. Ker Gawl, Fam. Ruscaceae) and the Japanese forest grass Hakonechloa macra (Munro) Honda (Poaceae). H. macra cultivar 'All Gold' is a cool-season ornamental grass commonly used as a border or pot plant, growing in short-clumps and making a waterfall effect that turns brilliant gold in autumn, contrasting with the foliage of other plants [43] (https://www.rhs.org. uk/). P. arundinacea is also a cool-season plant; however, cultivars are generally much taller, require abundant watering. It is even sometimes grown as an aquatic plant, in some cases being a very invasive species [43, 44]. Therefore, the disadvantages of this plant versus $L$. martinezii for sustainable xero-gardening are clear. Liriopogons in general, and in particular $L$. muscari displays a size and leaf length more similar to $L$. martinezii but they grow better in cooler environments and need more watering $[41,42]$. L. martinezii might be compared to C. comosum regarding aesthetic appeal and growth conditions. C. comosum cultivars develop green long leaves and is also drought-tolerant (although it grows better in more humid and fresh conditions) and is quite easy to grow as a houseplant and variegated cultivars (C. comosum 'Vittatum' and C. comosum 'Variegatum') are the most popular [40]. The generally smaller size of $L$. martinezii makes it a finer plant that might attract the attention of gardeners and people in general due to its novelty.

\section{What advantages does $L$. martinezii present in comparison to other native bulbous plants?}

The West Mediterranean Area has several native bulbs that show certain potential as ornamental plants in the xero-gardening subsector as they grow in dry or semi-arid environments $[18,20,25,26]$. Some of them bloom in spring and present beautiful flowers such as Anthericum, Narcissus, Asphodelus, Romulea, Tulipa and Ranunculus; whereas some others also display during the flowering period in summer or autumn e.g. Narcissus, Pancratium, Urginea, Merendera, Colchicum or Scilla. However, the flowering period of native bulbous plants is generally quite short and thus, the aesthetic value of leaves can be even more interesting than flowers as ornamentals. L. martinezii shows delicate white and bright flowers with a unique colour pattern of the leaves. When the bulbs grow in clumps they provide an original effect, both in the flowering period and the long vegetative stage (Figure 1), similar to that obtained with C. comosum. It could be used in different spaces in outdoor xero-gardening (grass-like foliage plant in borders in a winter garden, as an alpine bulb or pot plant) and maybe also as a houseplant. Unlike the above-mentioned spring-flowering genera, L. martinezii shows a longvegetative period and, therefore, the leaves last from the autumn until the summer. However, this trait can be also found in other autumn-flowering species. An example of native ornamentals bulbs with autumn flowering is the genus Sternbergia. For instance, S. lutea (L.) Ker Gawl. ex Spreng. shows similar leaf shape and features, similar clump-effect (although plants are generally smaller), leaves have a bright colour and do not present the central white band, which makes L. martinezii quite unique in this regard. In addition, Sternbergia is more demanding of humidity, which limits its introduction for xero-gardening. Other species showing similar potential might be found in Pancratium 
maritimum L. due to its beautiful and big white flowers, the long vegetative period, its environmental drought-tolerant specificity, as well as the remarkable information on its propagation [45-47]. According to this, $P$. maritimum could be, in principle, as versatile as L. martinezii. However, there are three main constraints that could limit its viability as a gardening plant. Firstly, the damping-off in $P$. maritimum seedlings has been described as a result of Fusarium proliferatum endogenous infection of some seed accessions from Spain [48]. This challenge could severely compromise the commercial production of this species as the quality of seeds and seedlings is not ensured. Secondly, P. maritimum is often colonised by Brithys crini, whose larvae produce apparent damages in stems, leaves, fruits and seeds of the plants $[45,46]$, acting as a garden pest in some parts of its range and in some other Liliaceae and Amaryllidaceae. This fact strongly limits its use as an ornamental both due to the plant defoliation and the common presence of the larvae on the leaves, whereas any kind of insect predation is neither described nor observed for L. martinezii. Finally, the adaptation of P. maritimum to alternative, commercial substrates appears to be quite difficult as the growth is highly dependent on sand presence (CIEF, data not published). Some experiments carried out in this institution showed that cultivation in any other substrate is very sensitive to watering (e.g. after rain, or during the process of adaptation to greenhouse cultivation). This feature highly restricts its potential introduction as a commercial gardening plant. In any case, the major strength of $P$. maritimum would only be restricted in the apparent flowering, which is limited to the summer period.

\section{What advantages does $L$. martinezii present for its industrial production in xero-gardening?}

Functional and sustainable landscapes and xero-gardens are created when attention is paid to minimising or alleviating abiotic and biotic stresses using techniques from plant selection and production to transplanting and finally maintenance of the established plants [9]. finding drought-tolerant plants or species that do not require abundant watering is a clear advantage for gardening. According to the available information on L. martinezii ecology, this bulbous plant is drought tolerant, it can be hardy and grows on different soil types. All these qualities make L. martinezii an interesting option for gardening as it seems it can be well adapted to culture conditions under Mediterranean environments without posing any particular demands. The propagation capacity of the target species is also an important trait to bear in mind when selecting plants for commercial purposes as plants with propagation difficulties obviously require more effort in their multiplication on an industrial scale. Research on seed germination, propagation and regeneration from tissue culture is a strategic need for the sustainable exploitation of new ornamental plants, as well as for breeding and selection of already existing crops $[4,49,50]$. In this regard, the best conditions for propagating L. martinezii from seeds have been recently published [27]. However, the time required to achieve the adult stage in bulbous plants usually takes some years $[3,5]$ which sometimes makes growing bulbs from seeds for industrial purposes unviable. In this regard, in vitro cultures offer better propagation rates than natural multiplication rates (both vegetative and sexual) in geophytes [5, 50-54]. Tissue culture of native plants has been used for mass propagation of selected native perennial plants that cannot be propagated on a large scale by means of seeds and cuttings [55]. Also, these techniques have been extensively applied to the most popular ornamental geophytes such as lily and Zantedeschia [56], daffodils [3, 53, 57, 
58] and orchids [59] among others [60]. In addition, these techniques are a prerequisite in most tools in biotechnology, especially in the context of breeding programs for transformation, improvement and new cultivar selection $[61,62]$. Some studies have also been made using in vitro techniques for L. martinezii propagation with successful yields [27, 63, 84]. An overview of the main achievements is shown in Table 1. For commercial purposes, establishing the optimal conditions for acclimatization ex vitro is an important challenge. However, in the case of L. martinezii, the results obtained suggested high acclimatization rates [63] thus overcoming one of the most important constraints in the micropropagation process.

Table 1. Summary of the available information on propagation of Lapiedra martinezii Lag

\begin{tabular}{|c|c|c|c|c|}
\hline Culture technique & Treatment & $\begin{array}{c}\text { Initial } \\
\text { propagation } \\
\text { success }\end{array}$ & $\begin{array}{l}\text { Transplantation } \\
\text { success }\end{array}$ & Reference \\
\hline Seed germination in vitro & $20^{\circ} \mathrm{C}$ in light-dark and dark conditions & $>90 \%$ & $100 \%$ & {$[27]$} \\
\hline Seed germination in vitro & $\begin{array}{l}\text { Pre-conditioning with } 0.01-0.75 \mathrm{~g} / \mathrm{L} \\
\mathrm{GA}_{3} \text { and cultivation in } 20^{\circ} \mathrm{C}\end{array}$ & $>90 \%$ & $100 \%$ & {$[27]$} \\
\hline Seed germination in vivo & $\begin{array}{c}\text { Peat moss: vermiculite } 5: 2 \\
\text { watered once a week }\end{array}$ & $90 \%$ & $100 \%$ & {$[84]$} \\
\hline Seedling culture in vitro & $\begin{array}{l}\text { Solid cultures in MS, Gamborg B5 } \\
\text { media with low sucrose content }\end{array}$ & Up to $85 \%$ & $86 \%$ & {$[84]$} \\
\hline $\begin{array}{l}\text { Bulb scales micropropagation } \\
\text { in solid media }\end{array}$ & $\begin{array}{l}\mathrm{BAP}=4 \text { and } \mathrm{NAA}=0,12 \mathrm{mg} / \mathrm{L} \\
\quad \text { in } \mathrm{MS} \text { solid medium }\end{array}$ & $\begin{array}{l}6 \text { new bulblils } \\
\text { per explant }\end{array}$ & $>70 \%$ & {$[63]$} \\
\hline $\begin{array}{l}\text { Bulb scales micropropagation } \\
\text { in liquid cultures }\end{array}$ & $\begin{array}{l}\text { Different combinations of BAP, } \\
\text { NAA and PAC in MS }\end{array}$ & $0-1$ & $\mathrm{Nd}$ & {$[84]$} \\
\hline Bulb swelling in vitro & $\begin{array}{l}\text { MS medium supplemented } \\
\text { with } 90 \mathrm{~g} / \mathrm{L} \text { sucrose }\end{array}$ & $\begin{array}{l}\text { Doubled } \\
\text { biomass }\end{array}$ & $\mathrm{Nd}$ & {$[63]$} \\
\hline $\begin{array}{l}\text { Micropropagation via callus } \\
\text { development in vitro }\end{array}$ & $\begin{array}{l}50 \text { combinations of BAP, NAA } \\
\text { and KIN in MS medium }\end{array}$ & 0 & $\mathrm{Nd}$ & {$[63]$} \\
\hline
\end{tabular}

$B A P$ 6-Benzylaminopurine, GA3 Gibberellic acid, KIN kinetin, $M S$ Murashigue and Skoog basal salts and vitamins, NAA $\alpha$-Naphtalenacetic acid, $N d$ Not determined, PAC Paclobutrazol.

\section{How the use of $L$. martinezii as an ornamental can affect the conservation status of wild populations?}

L. martinezii is a Southwest Mediterranean endemism restricted to some habitats in thermophilous areas [17-19, 28]. It is found in 22 habitats of European Community Interest according to D92/43/CEE [22]. It shows a relatively narrow extent of occurrence but the Spanish populations seem to be abundant enough (http://www.anthos.es). In contrast, very scarce information is found on its presence and abundance in North-Africa [19, 22]. Although no detailed population counting studies have been performed, local flora societies estimated average abundance in the Valencia Region [20] (http//bdb.cma.gva.es); occasional abundance in some areas of Murcia Region (http://www.regmurcia.com) and Almeria (http://www.almerinatura.com). L. martinezii 
is considered by the IUCN in the Mediterranean and Globally as Least Concern (https://www. iucnredlist.org/) as well in the Redlist of Andalusia [25]. However, [22] recently pointed out a decline in several Spanish populations mainly due to grazing pressure on young flowers and fruits that compromises sexual recruitment. The massive and uncontrolled harvesting for the chemical-pharmaceutical industry is an important potential risk to bear in mind, since wild plants belonging to the Amaryllidaceae still remain an important source of alkaloids [64,65]. However, there is no evidence of the collection for this species, unlike other Amaryllidaceae. Lycorine is the most abundant alkaloid in L. martinezii [21,22]. In spite of the wide range of bioactivities described for this alkaloid $[3,66]$ it is considered of minor importance for the pharmaceutical industry [3]. This is probably due to its toxicity [67], which makes its application in people quite difficult. However, lycorine is also an appreciated alkaloid in the chemical industry. It is mainly extracted from the bulbs of the Chinese Lycoris radiata (L'Hér.) Herb. and interest in this compound has been renewed in crop protection based on plant extracts [68, 69]. For these reasons, it seems to be reasonable to apply a certain vigilance due to the potential vulnerability of the natural populations. In addition, most of its populations are included in, or close to current or potential tourist areas along its distribution range. Although the tourist pressure seems to be decreasing in recent years in coastal and sub-littoral areas of Spain, the deep transformation and subsequent fragmentation of these natural environments does not allow easy population recovery as has happened for other littoral bulbous plants with Mediterranean distribution [45, 46, 70]. In this regard, L. martinezii is also found in Spain in at least 22 protected areas and one in Morocco [22], which makes us think that a number of populations will be kept unaltered in the long run, thus ensuring their good conservation status. Finally, the uncontrolled harvesting of germplasm (mainly bulbs) for horticultural purposes is a possible risk to bear in mind for this species as with other bulbous plants in the past such as daffodils [71, 72]. Although the species does not deserve current legal protection, population decline observed locally in some areas, as well as the potential threats mentioned above, lead us to recommend performing preventive conservation efforts; in this regard, cultivation could discourage attempts of illegal harvesting, as proposed in this paper. [27] suggested orthodox storage conditions for seeds as they tolerated moderate desiccation plus subzero storage conditions. This fact makes quite it easy and cheap to keep L. martinezii germplasm (seeds) by the usual methods in conventional seedbanks [29, 37, 73-75]. The conservation efforts especially directed towards endemic plants with current or potential economical interests (e.g. medicinal, ornamental, etc.) have been defended by several authors [76-78]. Moreover, the introduction of endemic, rare and/or threatened plants in the ornamental trade industry can be a conservation measure itself and has been proposed in some specific cases such as Convolvulus scindicus Stocks [77] and Ruellia linearibracteolata Lindau [79]. Domestication of endemic species of commercial interest, as a basis for the popularization of their crop, is aimed at reducing the pressure that exists in the natural populations of the species [37]. Therefore, actively promoting the cultivation of useful wild endemic, rare or threatened plant species e.g. by means of their revalorization and introduction in the ornamental plants trade would relieve the harvesting pressure on wild populations, thus alleviating the expenses of the public ex situ conservation strategies. 


\section{What other advantages does $L$. martinezii present as a foliage plant?}

Public health aspects must also be taken into consideration when planning the incorporation of ornamental grasses. On the one hand, it means restriction of planting of highly allergenic species and their exclusion from particular sites as playgrounds and school facilities and, on the other hand, avoiding the use of exotic and invasive species that may lead to the degradation of natural habitats [43]. Most of the ornamental grasses belong to the Poaceae $[40,43]$ such as P. arundinacea and H. macra. This family is recognized to produce high amounts of pollen which is a serious health risk for people with a predisposition to allergens $[43,80,81]$. L. martinezii, like the whole Amaryllidaceae family, is expected not to be allergenic as it is entomophilous and, unlike anemophilous taxa, they produce much smaller amounts of pollen [82]. As far as exotic species concerns, it is not well known what makes a species become invasive. It depends on functional differences between invaders and residents (variables determining population establishment and growth, ability to manage soil nutrients, lack of herbivores and other natural enemies, etc.) and susceptibility of certain ecosystems to disturbance [83-85]. It is not currently possible to determine the potential invasive capacity of $L$. martinezii with the information currently available and further research is needed to determine to what extent it could be introduced in different climatic areas. However, it seems to be suitable (at least) for cultivation in different environments within its range of distribution with some safety. Finally, $L$. martinezii seems not to be attacked by predators, unlike P. maritimum as we discussed above. In fact, non-systematized cultivation tests have been carried out by the staff of CIEF and it has been observed that there is no predation by herbivorous invertebrates (snails, slugs, etc.), unlike other species tested (Crinum, Galanthus, Narcissus). This situation can be attributed to the high alkaloid content in wild L. martinezii [21, 22]. Therefore, the use of phytochemicals for the maintenance of gardens, rocks, and so on, where the plant is integrated, is expected to be practically inexistent.

\section{CONCLUSIONS}

The aesthetic traits of this species are quite attractive and unique so it can be considered as a new plant for gardening. In addition, its ecology and distribution suggest that it could be quite well adapted under different production and culture conditions in dry and semi-arid regions and thus being suitable for xero-gardening. Finally, the horticultural traits so far determined (germination capacity, in vitro multiplication, in vitro rooting, acclimatization and survival of micropropagated plants) are interesting strengths for its industrial propagation and early domestication. This species faces some conservation challenges although it seems not to be severely threatened. For this reason, its introduction as an ornamental could be an appropriate preservation measure that complements conventional strategies such as seed banking and vigilance of wild populations. Finally, more in-depth research should be carried out on its agronomical behaviour (production in the nursery, salt stress, heat and transplantation tolerance, etc), its potential invasive behaviour, and even the possibility of improving some traits by means of breeding programs. 


\section{LITERATURE CITED}

[1] Sajjad Y, Jaskani MJ, Asif M, Qasim M. Application of plant growth regulators in ornamental plants: a review. Pak J Agri Sci. 2017;54(2):327-333.

[2] Simonetta F, Potenza G, Castronuovo D, Candido V. Wild geophytes of ornamental interest in the native flora of Southern Italy. Ital Agron. 2014;9(2):99-106. DOI:10.4081/ija.2014.595.

[3] Hanks, GR. Narcissus and Daffodicl, The genus Narcissus. Medicinal and Aromatic Plants Industrial Profiles, Horticulture Research International, Kirton, UK; 2002.

[4] Heywood, V. Conservation and Sustainable Use of Wild Species as Sources of New Ornamentals. Acta Hort. 2003;598:43-53.

[5] Rees, AR. The growth of bulbs. Applied aspects of the physiology of ornamental bulbous crop plants. Academic Press; 1969.

[6] Benschop M, Kamenetsky R, Le Nard M, Okubo H, De Hertogh A. The global flower bulb industry: production, utilization, research. Hortic Rev. 2010;36:1-117.

[7] Phillips S. Netherlands. GAIN Report Nr NL6026. Global Agricultural Information Network. USDA Foreign Agricultural Service. Washington DC; 2016.

[8] Hernández M, Morales A, Sauri D. Ornamental plants and the production of nature(s) in the Spanish real estate boom and bust: the case of Alicante. Urban Geogr. 2013; DOI: http://dx.doi. org/10.1080/02723638.2013.871813.

[9] Franco JA, Martínez-Sánchez JJ, Fernández JA, Bañón S. Selection and nursery production of ornamental plants for landscaping and xero-gardening in semi-arid environments. J Hortic Sci Biotechnol. 2016;81(1):3-17.

[10] Khan MA, Qaiser M. Halophytes of Pakistan: Characteristics, distributions and potential economic usages. In: Khan MA, Kust GS, Bart HJ, Böer B. Sabkha Ecosystems. Vol: II; 2006, p. 129-153.

[11] López J, González A, Fernández JA, Bañón S. Ornamental use of Labiales for Xeriscape in Mediterranean Area. Acta Hort. 2006;723:460-465.

[12] Franco JA, Martínez-Sánchez JJ, Fernández JA, Bañón S, Ochoa J, Vicente MJ. Nursery preconditioning of plants for revegetation, gardening and landscaping in semi-arid environments. Technology and knowledge transfer e-bulletin. 2010;1(2):1-5.

[13] Iglesias-Díaz MI, González-Abuín F. Investigating the rooting potential by cutting propagation in wild populations of heathers in NW Spain (Galicia). Acta Hort. 2004; 630:279-286.

[14] Junta de Andalucía. Producción intensiva de plantas autóctonas del sureste mediterráneo con fines ornamentales y paisajísticos. Artes gráficas. Novograf. Sevilla; 1998.

[15] Bishop M, Davis A, Grimshaw J. Snowdrops: a monograph of cultivated Galanthus. Maidenhead, UK: The Griffin Press; 2001.

[16] Meyer FG. Plant explorations: ornamentals in Italy, southern France, Spain, Portugal, England and Scotland. United States Department of Agriculture-Longwood Gardens of the Longwood Foundation, Washington, USA; 1959.

[17] Aedo C. Lapiedra. In: Castroviejo S, Aedo L, Laínz M, Muñoz Garmendia F, Nieto Feliner G, Paiva J, Bened C. Flora Ibérica 8. Madrid: Real Jardín Botánico, CSIC; 2010, p. 149-152. 
[18] Bolòs O, Vigo J. Flora dels Països Catalans. Volumen IV (Monocotiledònies). Barcelona: Editorial Barcino; 2001.

[19] Maire R. Flore de l'Afrique du Nord, V. 6. Paris: Ed. Lechevalier; 1959.

[20] Mateo G, Crespo MB. Manual para la determinación de la flora valenciana. Alicante: Compás; 2010.

[21] Larsen MM, Adsersen A, Davis AP, Lledó MD, Jäger AK, Rønsted N. Using a phylogenetic approach to selection of target plants in drug discovery of acetilcholinesterase inhibiting alkaloids in Amaryllidaceae tribe Galantheae. Biochem Syst Ecol. 2010;38:1026-34.

[22] Ríos S, Berkov S, Martínez-Francés V, Bastida J. Biogeographical patterns and phenological changes in Lapiedra martinezii Lag. (Amaryllidaceae) related to its alkaloid diversity. Chem Biodivers. 2013;10:1220-38.

[23] Suau R, Gómez A, Rico, R. Ismine and related alkaloids from Lapiedra martinezii. Phytochemistry. 1990:29(5):1710-12.

[24] Suau R, Gómez AI, Vázquez-Tato MP, Castedo L, Riguera R. 1988. Alkaloid N-oxides of Amaryllidaceae. Phytochemistry. 1988;27(10):3285-87.

[25] Blanca G, Cabezudo B, Cueto M, Morales Torres C, Salazar C. Flora Vascular de Andalucía Oriental: $2^{\mathrm{a}}$ versión corregida y aumentada. Granada: Universidades de Almería, Granada, Jaén y Málaga; 2011.

[26] Sánchez-Gómez P, Guerra J. Nueva flora de Murcia. Plantas Vasculares. Diego Marín S.L.; 2011.

[27] Juan-Vicedo J, Fernández-Pereira J, Ríos S, Casas JL, Martin I. Seed germination and storage behaviour of Lapiedra martinezii (Amaryllidaceae). Seed Sci Technol. 2016;44(1):199-206. DOI: $10.15258 /$ sst.2016.44.1.02

[28] Galicia D, Moreno L, Moreno JC. Cartografía Corológica Ibérica. Aportaciones 46-46. Bot Complut. 1993;18:322-8.

[29] Ballesteros D, Meloni F, Bacchetta G., editors. Manual for the propagation of selected Mediterranean native plant species. Cagliari: Ecoplantmed, ENPI CBC-MED; 2015.

[30] Evans M. Why use natives? Fremontia. 2013;40-41(3-1):2-6.

[31] Ochoa J, Muñoz M, Vicente MJ, Martínez-Sánchez JJ, Franco JA. Native ornamental species for urban landscaping and xero-gardening in semi-arid environments. Acta Hortic. 2010;881:42528. DOI: https://doi.org/10.17660/ActaHortic.2010.881.68.

[32] Ferrer-Gallego PP, Ferrando I, Gago C, Laguna E. Manual para la conservación de germoplasma y el cultivo de la flora valenciana amenazada. Conselleria d'Infraestructures, Territori i Medi Ambient. Valencia: Generalitat Valenciana; 2013.

[33] Mullaj A, Hoda P, Shuka L, Miho A, Bego F, Qirjo M. About green practices for Albania. Albanian J Agric Aci. 2017;31-50.

[34] Aguilella A, Fos S, Laguna E. Catálogo Valenciano de Especies Amenazadas de Flora. Conselleria de Medi Ambient, Aigua, Urbanisme i Habitatge. Valencia: Generalitat Valenciana; 2010.

[35] Given DR. Principles and Practice of Plant Conservation. Portland: Timber Press; 1994.

[36] Hamilton A, Hamilton P. Plant Conservation: An ecosystem approach. London: Earthscan; 2006.

[37] Laguna E. Flora rara, endémica o amenazada de la Comunidad Valenciana. Generalitat Valenciana, Conselleria de Medio Ambiente; 1998. 
[38] Laguna E, Deltoro VI, Pérez-Botella J, Pérez-Rovira P, Serra L, Olivares A, Fabregat C. The role of small reserves in plant conservation in a region of high diversity in eastern Spain. Biol Conserv. 2004;119(3):421-26.

[39] Sharrock S, Jones M. Conserving Europe's threatened plants. Progress towards Target 8 of the Global Strategy for Plant Conservation. Richmond, Surrey: BGCI; 2009.

[40] Blessington TM, Collins PC. Foliage plants: prolonging quality: postproduction care and handling. Batavia (USA): Ball Publishing; 1993.

[41] Lattier JD, Ranney TG. Identification, Nomenclature, Genome sizes and ploidy levels of Liriope and Ophiopogon taxa. Hort Sci. 2014;49(2):145-51.

[42] Nesom GL. Overview of Liriope and Ophiopogon (Ruscaceae) naturalized and commonly cultivated in the USA. Phytoneuron. 2010;56:1-31.

[43] Tomaškin J, Tomaškinová J, Kizeková M. Ornamental grasses as part of public green, their ecosystem services and use in vegetative arrangements in urban environment. Thaiszia. J Bot Košice. 2015;25(1):1-13.

[44] Lavergne S, Molofsky J. Reed Canary Grass (Phalaris arundinacea) as a Biological Model in the study of plant invasions. CRC Crit Rev Plant Sci. 2004;23(5):415-29. DOI: 10.1080/07352680490505934

[45] Balestri E, Cinelli F. Germination and early seedling establishment capacity of Pancratium maritimum L. (Amaryllidaceae) on coastal dunes in the north western Mediterranean. J Coast Res. 2004;20(3):761-70.

[46] Grassi F, Cazzaniga E, Minuto L, Peccenini S, Barberis G, Basso B. Evaluation of Biodiversity and Conservation strategies in Pancratium maritimum L. for the Northern Tyrrhenian Sea. Biodivers Conserv. 2005;14(9):2159-69.

[47] Nikopoulos D, Nikopoulou D, Alexopoulos AA. Methods for the preservation of genetic material of Pancratium maritimum (Amaryllidaceae). J Food Agric Environ. 2008;6:538-46.

[48] Palmero D, García M, Gálvez L, Juan-Vicedo J, Martin I. Etiología de la podredumbre radicular y camping off de la azucena de mar. (p134). Libro de resúmenes del XVII Congreso de la Sociedad Española de Fitopatología; 2014.

[49] Engelmann F. Use of biotechnologies for conserving plant biodiversity. Acta Hortic. 2009;812:6381.

[50] Tasheva K, Kosturkova G. Role of Biotechnology for Protection of Endangered Medicinal Plants. Environmental Biotechnology - New Approaches and Prospective Applications; 2013.

[51] De Klerk GJ. Why plants Grow in Tissue Culture: questions, answers and exciting prospects. Prophyta Annual. 2010:42-44.

[52] Kim KW, De Hertogh AA. Tissue culture of ornamental flowering geophytes. Hortic Rev. 1996;18:87-169.

[53] Ziv M, Lilien-Kipnis H. Bud regeneration from inflorescence explants for rapid propagation of geophytes in vitro. Plant Cell Rep. 2000;19:845. DOI: https://doi.org/10.1007/s002990000204

[54] Van Rossum MWPC, Alberda M, Van der Plas LHW. Role of oxidative damage in tulip bulb scale micropropagation. Plant Sci. 1997;130:207-16.

[55] George EF. Plant Propagation by Tissue Culture. The Netherlands: Springer; 2008. 
[56] De Klerk GJ. Micropropagation of bulbous crops: technology and present state. Floriculture Ornamental Biotech. 2012;6(1):1-8.

[57] Iqbal J, Mumtaz M, Khan B, Fatima M, Abbas M. In vitro propagation of 'hybrid tea' roses. Pak J Agri Sci. 2003;40(3 - 4):155-63.

[58] Squires WM, Langton FA. Potential and limitations of Narcissus micropropagation: An experimental evaluation. Acta Hort. 1990;266:67-73.

[59] Qasim M, Khan IA, Jaskani MJ. In vitro propagation of orchid. Pak J Agri Sci. 1994;31(1):3033.

[60] Hvoslev-Eide AK, Preil W. Liquid culture systems for in vitro plant propagation. Springer; 2005.

[61] Hafeez I, Sadia B, Sadaqat NA, Kainth, RA, Iqbal MZ, Khan IA. Establishment of efficient in vitro culture protocol for wheat land races of Pakistan. Afr J Biotechnol. 2012;11(11):2782-2790.

[62] Kanwal M, Ahmad Joyia F, Mustafa G, Anjum Z, Rana IA, Khan MS. Direct in vitro regeneration of Nicotiana plumbaginifolia L. and the potential for genetic transformation. Int J Hortic. 2017;7(6):40-46. DOI: 10.5376/ijh.2017.07.0006

[63] Juan-Vicedo J, Pavlov A., Ríos S, Casas JL. In vitro culture and micropropagation of the BaeticMoroccan endemic plant Lapiedra martinezii Lag. (Amaryllidaceae). In Vitro Cell Dev BiolPlant. 2019;55:725-32. DOI: https://doi.org/10.1007/s11627-019-10031-5

[64] [64] Georgieva L, Berkov S, Kondakova J, Bastida J, Viladomat F, Atanassov A, Codina C. Alkaloid variability in Leucojum aestivum from wild populations. Z. Naturforsch. 2007;62(910):627-35.

[65] Berkov S, Bastida J, Viladomat F, Codina C. Development and validation of a GC-MS method for rapid determination of galanthamine Leucojum aestivum and Narcissus ssp.: a metabolomic approach. Talanta. 2011;83:1455-65.

[69] Shen JW, Ruan Y, Ren W, Ma BJ, Wang XL, Zheng CF. Lycorine: a potential broad-spectrum agent against crop pathogenic fungi. J Microbiol Biotechnol. 2014;24(3):354-58.

[70] Demur Z, Müderrisoğlu H, Aksoy N, Özkan Ş, Uzun S, Özkara H. Effects of second housing and recreational use on Pancratium maritimum L. population in western Black Sea region of Turkey. J Food Agric Environ. 2010;8(2):890-94.

[71] Miller P. The Gardeners Dictionary. London: John \& James Rivington; 1754.

[72] Parkinson J. Paradisi in Sole, Paradisus Terrestris. London: Lownes and Young; 1629.

[73] Hay FR, Probert RJ. Advances in seed conservation of wild plant species: a review of recent research. Conserv Physiol. 2013; 1(1):1-11. DOI: 10.1093/conphys/cot030

[74] Bacchetta G, Bueno A, Fenu G, Jiménez-Alfaro B, Mattana E, Piotto B, Virevaire M. Conservación ex situ de plantas silvestres. Oviedo: Principado de Asturias, La Caixa; 2008.

[75] Walters C. Genebanking seeds from natural populations. Nat Area J. 2015;35(1):98-105.

[76] Shinwari ZK, Qaiser M. Efforts on conservation and sustainable use of medicinal plants of Pakistan. Pak J Bot. 2011;43:5-10.

[77] Abbas HM, Qaiser M, Khan SW. In vitro response of Convolvulus scindicus to different growth hormones - an attempt to conserve an endangered species. Pak J Agri Sci. 2012;49(1):41-45.

[78] Hwang HW. Plant diversity and conservation in China: planning a strategic bioresource for a sustainable future. Bot J Linn Soc. 2011;166:282-300. 
[79] Abbas H, Qaiser M. Ruellia linearibracteolata: conservation assessment and strategies to avoid extirpation. Pak J Bot. 2011;43(5):2351-57.

[80] D'Amato G, Cecchi L, Bonini S, Nunes C, Annesi-Maesano I, Behrendt H, Liccardi G, Popov T, Van Cauwenberge P. Allergenic pollen and pollen allergy in Europe. Allergy. 2007;62(9):97690. DOI: $10.1111 /$ j.1398-9995.2007.01393.x

[81] Reddi S, Reddi, NS. Pollen production in some anemophilous angiosperms. Grana 1986;25:5561.

[82] Hjelle KL. Relationships between pollen and plants in human-influenced vegetation types using presence-absence data in western Norway. Rev Palaeobot. 1997;99(1):1-16.

[83] Keane RM, Krawley MJ. Exotic plant invasions and the enemy release hypothesis. Trends Ecol Evol. 2002;17(4):164-170.

[84] Levine JM, Vila M, D’Antonio CM, Dukes SJ, Grigulis K, Lavorel S. Mechanisms underlying the impacts of exotic plant invasions. Proc R Soc Lond. 2003;270:775-781. DOI: 10.1098/ rspb.2003.2327.

[85] Rejmanek M, Richardson DM. What attributes make some species more invasive? Ecology. 1996;77(6):1655-61.

[86] Juan-Vicedo J. In vitro propagation and ex situ conservation of the Western-Mediterranean endemic species Lapiedra martinezii Lag. (Amaryllidaceae). Doctoral Thesis. Alicante: San Vicent del Raspeig; 2016. http://hdl.handle.net/10045/70217 